\title{
SALT-TOLERANCE OF FRESH-WATER FISH GROUPS IN RELATION TO ZOOGEOGRAPHICAL PROBLEMS
}

\author{
BY \\ GEORGE S. MYERS \\ Stanfort University
}

\section{INTRODUCTION}

The distribution of fresh-water fishes like that of other groups, has been widely utilized by zoogeographers, but with widely divergent acumen and success. At one extreme are those non-ichthyologists who have uncritically utilized for evidence certain groups whose distribution happens to support whatever theory they may be espousing. At the other extreme is the work of careful ichthyologists like DE BEAUFORT (I9I3) and REGAN (1922) whose thorough knowledge of the groups with which they are working demands the most careful consideration of their conclusions.

However, no zoogeographer who utilizes the evidence of diverse groups can be familiar at first hand with all of them, and the difficulty facing such workers is that of seeking out the really dependable evidence in those groups he does not know well. Aside from the difficulty of selecting dependable authorities or systematic works, the zoogeographer desiring to use the evidence of fresh-water fishes has another troublesome matter to contend with. This is the differing tolerance of salt-water exhibited by different groups of fresh-water fishes. As one example, and one which has frequently troubled zoogeographers, we may mention the Galaxiidae, fresh-water fishes of Southern South America, Africa, Australia, and New Zealand, whose distribution has been held by some to be evidence for continental drift or southern intercontinental land-bridges. Ichthyologists now know that these fishes are, as a group, salt-tolerant and possibly either anadromous or catadromous, and that they are not really strong evidence for continental connections simply because it seems possible that they may cross ocean barriers.

Several systems of classifying fishes according to their salt tolerance have been attempted by ichthyologists for zoogeographical purposes. Without referring to the literature of the past century, we may take as an example the important but now somewhat outdated paper by Boulenger (Igo6) on 
the distribution of African fresh-water fishes, in which he divides freshwater fishes into four categories, as follows:

"I. Those living part of the year in the sea. This category is again subdivided into anadromous forms, breeding in fresh water (ex. some Clupea), and catadromous forms, breeding in salt water (ex. Anguilla).

"2. Those living normally in the sea, but of which certain colonies have become land-locked, or have separated themselves from the marine stock represented on the neighbouring coast (ex. some Gobiidae and Blenniidae).

"3. Those which, although entirely confined to fresh waters, have as nearest allies species living in the sea, and which there is reason to regard as more or less recently derived from marine forms (ex. Galaxiidae, Tetrodontidae).

"4. Those belonging to families entirely (ex. Mormyridae, Characinidae) or chiefly (ex. Siluridae, Cyprinodontidae) restricted to fresh waters."

- This classification of Boulenger was followed by Pellegrin in a series of subsequent zoogeographical papers, principally on African and Madagascan fishes (see especially Pellegrin,I933). Regan (I908, p. xii) also succinctly stated, in effect, that fishes corresponding to Boulenger's divisions I, 2 and 3 are of little importance in zoogeographical studies (see also REGAN, I922; DE BEAUfORT, I926, etc.).

Nichols (1928), without reference to the several pertinent papers of BouLenger, Pellegrin and Regan, proposes to separate fresh-water fishes into two vaguely defined divisions: continental, corresponding, we may presume, to Boulenger's division 4; and peripheral, "made up of elements with bettermarked affinities to salt-water groups". However, he includes in the latter such a strictly fresh-water family as the pikes (Esocidae). Nichols presents this same system again in 1943 (p. 3).

In addition, a number of categories and descriptive terms referring to salttolerance in animals have been proposed, but chiefly from a purely ecological viewpoint and more often with reference to marine forms (see HESSE, AlLEE, and Schmidt, 1937, p. I3). However, such terms as steviohaline, which has been applied equally to strictly marine and strictly fresh-water animals, and contranatant and denatant (see MEeK, I9I6, p. I9), have little practical application in general zoogeography. The term euryhaline (with wide salt-tolerance) has more zoogeographical value, and has been used by Pellegrin (I933, p. 2 I ; I934, p. 425) as equivalent to Boulenger's group I and 2, although evidently with a clear realization of its minor importance in purely zoogeographical work.

Ten years ago, in connection with a study of West Indian fresh-water fishes, I presented an exceedingly brief summation of modern knowledge of continental fresh-water fish distribution (MYERS, 1938). In preparing that paper, it became evident that the fishes which previous workers had considered to be true fresh-water fishes (equal to Boulenger's division 4 or to Nichols' continental division) really consisted of two elements (each composed of 
diverse systematic groups) which differ clearly and regularly in certain important details of their distributional patterns. One element, which I called the primary division, is rigidly and only with unimportant exceptions confined to the fresh-waters of continents and of islands which we know to have been connected with the continents during the Cenozoic. The other, which I called the secondary division, occurs where the primary division does, but in addition, also occurs on many islands the continental connections of which are either dubious or known not to have existed during the Cenozoic. Moreover, evidence was already sufficient to show that members of the secondary division, even ones which never enter brackish or salt water, are more salt-tolerant than primary division fishes, again with only the most unimportant exceptions. I did not attempt, in 1938 , to classify any of the still more salt-tolerant groups.

Since I938, two zoogeographers (MAYR, I944; DARLIngton, IO48) have found my division of fresh-water fishes of some value in interpreting fish distribution. Darlington has utilized these divisions in an extremely wellthought-out general scheme of fresh-water fish distribution. However, there has been some doubt, both unpublished and published (see especially GosLine, 1944, pp. 214-215), expressed as to the real distinctiveness of the two divisions. Furthermore, in my very brief exposition of 1938 it was impossible to present much evidence and to carry out the analysis of salt-tolerance in fresh-water fish groups beyond the two divisions mentioned. These omissions are in some measure corrected here.

\section{SALT-TOLERANCE IN FRESH-WATER FISHES}

The entire subject of salt-tolerance in fishes is needful of a great deal of new work. Most of what is known is derived from brief observations of the natural movements of fishes in relation to salt and fresh water, and most of this is scattered through the ichthyological literature in incidental references, often in the most obscure places, or even unpublished. For example, it has been presumed that the marine Pomacentridae are strictly stenohaline saltwater fishes. Yet InNes (I942, p. 439) and other aquarists have been able to acclimate Pomacentrus fuscus to pure fresh water 1. Again, it is widely known that at least one species of Cyprinodon (varlegatus) is semi-marine in its habits, but it has not yet been sufficiently remarked that the inland species of this genus are apparently restricted to alkaline waters. Observations such as those of GUNTER (I942), on the penetration of the sea by fresh-water fishes and of fresh water by marine forms, are of very great help, but they are not as conclusive in some ways as we could wish.

Much information upon salt-tolerance of fishes is to be found in studies

I) It is interesting (but still not explained) that such acclimated fresh-water $P$. fuscus frequently suddenly die when their aquarium is sharply tapped, as with a piece of metal against the glass. 
on osmotic regulation (see KROGH, I939, for a summary and bibliography) but most of this work has comparatively little bearing directly on the reasons for the differing salt-tolerance of systematic groups of fishes. The most important of these studies, from the zoogeographical standpoint, has been the work of Homer Smith and his associates on the physiology of excretion and the morphology of the kidney in fishes (see especially SмITH, 1932). However, there has yet been no thorough physiological study of systematic groups of fresh-water fishes to determine why they are confined to fresh water.

The important fact is that several large families of fishes (Cyprinidae, Characidae, Loricariidae, Mormyridae, etc.) are observably so strictly confined to fresh water that finding of any of them in salinities approaching that of the sea is very uncommon ${ }^{2}$ ), and records of them in sea water of average salinity are excessively rare. Moreover, this apparently ancient physiological inability to survive in the sea "... binds them to the land as securely as any known animals. Secondly, on the land, they are inescapably confined to their own particular drainage systems and can migrate from one isolated stream basin to the next only through the s.ow physiographical change of the land itself." (MYERS, I938, p. 343.)

The importance of such terrestrially-limited and slowly migrating animals in studies of terrestrial zoogeography is obvious, as I pointed out in 1938, and the exceptions to their fluviatile limitation are so rare as not to affect the general picture in the slightest. This importance is the chief reason for my segregation of such fishes as primary fresh-water fishes.

On the other hand a number of groups of fresh-water fishes which most zoogeographers have taken to be just as intolerant of salt water as my primary division are in fact not so limited. Among them are the Cichlidae, which some zoogeographers have utilized as evidence of the former connection of Africa to South America or of Madagascar to the mainland. Haseman (I9I I, p. 3 5 ) long ago experimented with the transfer of the Neotropical cichlid, Geophagus, to sea water and demonstrated how much more resistant to salinity it is than the characins, Astyanax, Acestrorhynchus, and Hoplias. My own example (1938, p. 345) of Tilapia in sea water has been reinforced by a subsequent report on the same individual fishes by Nigrelli (1940, pp. 535, 549). These presumably fresh-water fishes were caught in brackish water and survived for seven years in pure sea water. Aquarium experience shows that many other cichlids will survive high salinity.

Another such family is that of the ancient ganoids, Lepisosteidae. While some of the few existing species have not yet been reported to enter brackish water, Mr. Percy Viosca, the eminent zoologist of New Orleans, tells me

2) The occurrence of many fresh-water fishes in the Baltic is due to the low salinity of that sea, the upper parts of which are practically fresh (see EkMAN, 1935, pp. I76-186). 
that he has seen the great alligator gars, Lepisosteus spatu!a, commonly lying in sea water off the passes of the Mississippi delta ${ }^{3}$ ). All such salt-tolerant but obviously fresh-water fishes I call secondary fresh-water fishes.

Another division of fresh-water fishes is composed of representatives of primarily marine families which have taken up permanent resdence in fresh water. Many of them have evolved purely fresh-water species and genera. We find fresh-water sharks (Carcharhinus nicaraguensis), rays (Disceus thayeri, Potamotrygion), herrings (Pellonula and its allies), anchovies ( $\mathrm{Am}$ plova alleni), atherinids (Chirostoma, Labidesthes), sea-basses (Lates niloticus, Siniperca, Percichthys), croakers (Aplodinotus, Plagioscion), codfishes (Lota), and dozens of others. It is certain that nearly all of these are relatively recent colonizers of fresh waters, since all of them are closely related to existing marine genera and species, and it is probable that almost all retain a high salt-tolerance even though they may never normally enter the sea. Some of them may be of considerable importance in studies of terrestrial zoogeography, but in this they are usually much inferior to the primary division. Since they are all representatives of marine groups, we might call them vicarious fresh-water fishes.

Among the recent marine invaders of fresh waters is a small group with an interesting distributional pattern. In most parts of the world we find occasional small streams, mostly flowing directly into the sea and therefore not forming part of a major stream system, into which none or only a few species of the general primary (or secondary) fresh-water fish fauna have been able to penetrate. In the tropics round the whole world, we are likely to find that the dominant fishes in such streams are of two genera, a grey mullet (Agonostomus) and a certain peculiar type of gobies (Sicydium or a close ally). In the American tropics another genus usually accompanies them, a marine cling-fish (Gobiesox). These fishes are relatively rare or absent in any stream where primary fresh-water species are numerous, but in streams unoccupied by the primary division, whether it be on a continent, on a large continental island, or on the most remote of oceanic islands, these particular genera ${ }^{4}$ ) become dominant. They appear in small coastal streams draining the Venezuelan and Colombian highlands, in the West Indies, in the Galapagos, on Cocos Island, in Madagascar and Reunion, in the Indo-Australian Archipelago east of Wallace's Line (DE BEAUfort, I9I3), in Hawaii, and

3) Gunter (1942, p. 306) has recorded one specimen of the Mississippi paddlefish, Polyodon, from brackish water. Other such records, if authenticated, might show that this species should not be called a primary fresh-water fish, but this is of little moment, since there are only three existing species of this ancient family, one in China and two (one not yet described) in the Mississippi.

4) Agonostomus has been known under several generic names (see ScHultz, 1946). Sicydium, Sicyopterus, Sicyopus, Cotylopus, etc., are so close as practically to form one genus. There are many species of Sicydium and several of Agonostomus. Joturus of Cuba and Central America is close to Agonostomus, as is Cestraeus. 
in the Marquesas. Sicydium migrates to the sea and is distributed by sea. The habits of Agonostomus and the clingfishes are unstudied but probably they also go to sea at some part of the life cycle. Ichthyologists often miss them entirely while collecting. The remarkable complementary relation of these fishes to the primary division would make it seem useful to call them complementary fresh-water fishes.

Of a different type are the truly migratory fishes which move back and forth between fresh and salt water at a definite period of their life history, usually to spawn. To these the adjectives anadromous and catadromous are generally applied, but some authors have used these terms in a much wider sense. The resulting confusion, and the fact that these two terms do not at all cover some types of sea-river migration now known has made it necessary to reconsider the terminology (MYERs, 1949). One solution would be a term which covers all of the several types of sea-river migration, in either direction, and for this I have used diadromous. The diadromous fishes, since they spend a part of their lives at sea, can be distributed by sea, which greatly reduces their usefulness in most terrestrial zoogeographic work.

Finally, there are those non-migratory marine fishes which enter fresh water only sporadically, and which may therefore be called sporadic fresh-water fishes. They are of no value at all in terrestrial zoogeography.

\section{THE DIFFERENT PATTERNS OF FRESH-WATER FISH DISTRIBUTION}

Although recognition of the more important divisions of fresh-water fishes mentioned above is based primarily upon salt-tolerance, the most striking thing about them, to the zoogeographer, is the difference in their distributional patterns. It is this difference in pattern, which makes the recognition of the divisions useful to the zoogeographer, and which has convinced me that the groupings have considerable basis in fact. In attempting to demonstrate these pattern differences I shall have to assume that readers are familiar with my 1938 paper and with that of DaRLington, in which the basic arguments are presented and the composition of the primary and secondary divisions is set forth.

Primary fresh-water fishes may be taken as the starting-point, since they form the bulk of fresh-water fishes. They are widely distributed and abundant on all the continents save Australia, which has only two species of ancient type (one dipnoan and one osteoglossid). Their inter-continental relationships show that they have been distributed wholly by means of land and drainagebasin connections, never by sea. They have never reached Madagascar, the West Indian islands, or any oceanic island, save by human introduction. Except for the primitive lung-fishes and osteoglossids, they have never been able to pass Wallace's Line, except for a very few species which have gained a slight toe-hold to the east of it. Everything about their distributional pattern demonstrates that they cannot cross barriers of sea-water. Only a single 
species out of the six thousand or more forming this division has been demonstrated to survive in sea water (Acahara hakonensis of Japan).

Secondary fresh-water fishes show, by similarity of their distributional patterns, that they usually employ the same methods of dispersion as do primary ones. They are seldom or never present on true oceanic islands, except for a few semi-marine members of some of the component families (such as Fundulus on Bermuda). But they have reached and colonized the West Indian islands, Madagascar, the Seychelles, Celebes, Timor, and Luzon, although the families which have done this are probably of relatively recent origin, compared to the great bulk of the primary division. Of the older secondary types Lepisosteus has colonized Cuba. Much of this colonization must have been in the late Tertiary, and must therefore have been in part across sea barriers. The distributional pattern indicates plainly that most secondary fresh-water fishes are not regularly distributed by sea, but that narrow sea barriers can be crossed.

Vicarious fresh-water fishes are obviously directly or indirectly derived from rather recent marine ancestors. Vicarious types together with diadromous and sporadic ones, compose most of the fresh-water fish fauna of Australia, New Guinea, and a large part of that of Madagascar and the Philippines. They come in to fill the place of the absent primary fishes.

Complementary fishes have a very irregular distribution, and all the forms known to me are tropical. Wherever the primary fishes are few or absent they appear in numbers. Probably the large vicarious fauna in Australia also excludes them, but on this there is no information. They are plainly distributed by sea, and all may be diadromous.

Diadromous fresh-water fishes show by their distribution that they are distributed by sea and their presence in the fresh-water fish fauna is often an indicator more of the composition of the marine than of the freshwater fauna.

Sporadic fresh-water fishes are named only that they may be excluded from consideration in terrestrial and fluviatile zoogeography, but this is sufficient reason.

\section{RECAPITULATION}

We may recapitulate our salt-tolerant classification of fresh-water fishes as follows :

I. Primary. Strictly intolerant of salt water (Dipnoi, Polypteridae, Cyprinidae, Characidae, most siluroids, Centrarchidae, Percidae, etc.).

II. Secondary. Rather strictly confined to fresh water but relatively salttolerant, at least for short periods (Cichlidae, Synbranchidae, Lepisosteidae, most Cyprinodontidae and Poeciliidae).

III. Vicarious. Presumably non-diadromous fresh-water representatives of primarily marine groups (Labidesthes, Siniperca, Lota, etc.).

Bijdragen tot de Dierkunde, Afl. 28. 
IV. Complementary. Fresh-water forms, often or usually diadromous, belonging to primarily marine groups, which become dominant in fresh water only in the scarcity or absence of division I or II (and possibly III) (Agonostomus, Sicydium, certain New World Gobiesox).

V. Diadromous. Fishes which regularly migrate between fresh and salt water at a definite stage or stages of the life-cycle (Entosphenus, Alosa, Oncorhynchus, Anguilla, Sicydium) (See Myers, 1949).

VI. Sporadic. Fishes which live and breed indifferently in salt or fresh water or which enter fresh water only sporadically and not as part of a true migration.

\section{LITERATURE}

BEAUForr, L. F. DE, 19I3. Fishes of the eastern part of the Indo-Australian Archipelago, with remarks on its zoogeography. Bijdr. tot de Dierk., vol. I9, pp. 95-164.

Boulenger, G. A., 1906. The distribution of African fresh-water fishes. Rept. Brit. Assoc. Adv. Sci., S. Africa, 1905, pp. 412-432.

Darlington, P. J., I948. The geographical distribution of cold-blooded vertebrates. Quart. Rev. Biol., vol. 23, pp. 1-26, 105-123.

Ekman, Sven., 1935. Tiergeographie des Meeres. Leipzig, xii, 542 pp.

Gosline, W. A., I944. The problem of the derivation of the South American and African fresh-water fish faunas. Anais Acad. Bras. Ciencias, vol. 16, pp. 21 1-223.

Gunter, G., 1942. A list of the fishes of the mainland of North and Middle America recorded from both freshwater and seawater. Amer. Midl. Nat., vol. 28, pp. 305-326.

Haseman, J. D., I9II. Descriptions of some new species of fishes and miscellaneous notes on others obtained during the expedition of the Carnegie Museum to central South America. Ann. Carnegie Mus., vol. 7, pp. 315-328.

Hesse, R., Allee, W. C., and Schmidr, K. P., 1937. Ecological animal geography. New York, xiv, 597 pp.

InNes, W. T., I942. Exotic aquarium fishes. 4th Ed. Philadelphia, 496 pp.

KROGH, A., 1939. Osmotic regulation in aquatic animals. Cambridge, $242 \mathrm{pp}$.

MAYR, E., r944. Wallace's line in the light of recent zoogeographic studies. Quart. Rev. Biol., vol. I9, p. I-I4.

MeEK, A., I916. The migrations of fish. London, $x x, 427 \mathrm{pp.}$

Myers, G. S., I938. Fresh-water fishes and West Indian zoogeography. Ann. Rept. Smithsonian Inst. for 1937 , pp. 339-364.

- 1949. On the usage of anadromous, catadromous and allied terms for migratory fishes. Copeia, 1949 (in press).

Nrchols, J. T., 1928. Fishes from the White Nile collected by the Taylor expedition of 1927; a discussion of the fresh-water fish faunae of Africa. Amer. Mus. Novit., no. 319,7 pp.

- 1943. The fresh-water fishes of China. Natural History of Central Asia, vol. 9, xxxvi, 322 pp.

Nigrelli, R. F., 1940. Mortality statistics for specimens in the New York Aquarium, 1939. Zoologica, N. Y., vol. 25, pp. 525-552.

Pellegrin, J., 1933. Les poissons des eaux douces de Madagascar. Mem. Acad. Malgache, Tananarive, vol. 14, 224 pp., 3 pls.

- 1934 . La faune ichtyologique des eaux douces de Madagascar. Ann. Sci. Nat., ser. bot. zool., ser. I0, vol. I7, pp. 425-432.

Regan, C. T., I908. Biologia Centrali-Americana. Pisces, xxxii, 203 pp., 26 pls.

- 1922. The distribution of the fishes of the order Ostariophysi. Bijdr. tot de Dierk., vol. 22, pp. 203-207.

Schultz, L. P., 1946. A revision of the genera of mullets, fishes of the family Mugilidae Proc. U. S. Nat. Mus., vol. 96, pp. 377-395.

Smith, Homer W., 1932. Water regulation and its evolution in the fishes. Quart. Rev. Biol., vol. 7, pp. I-26. 